\title{
A behavioural approach to feeding broilers*
}

\author{
Michel Picard**, Michèle Plouzeau, Jean Michel Faure
}

Station de recherches avicoles, Inra, 37380 Nouzilly, France

(Received 24 August 1998; accepted 28 January 1999)

\begin{abstract}
Chicks use their beaks in the hatching process and pecking is one of the chick's first activities after hatching. Pecking is a precisely controlled action modulated by visual and tactile cues of the physical characteristics of feed particles. Post-ingestive nutritional effects of the feed are memorised and are coupled with sensory cues to let the chicken identify the feed. Some interactions between nutritional factors (amino acid and energy balance, feeding regimen) and other environmental factors (temperature, light) are discussed in this review. Both the nutritional content and physical characteristics of the diet in concert with other constraints such as climate modulate feed intake and the rhythm and efficiency of pecking at feed by broilers. Further developments in feed milling processes that control the physical characteristics of the feed particles might facilitate the efficiency of pecking ('feed prehension') in general, and feed identification after a new feed delivery. Under commercial conditions, feed intake behaviour of chickens can be measured by focal sampling of broilers between two periods of rest or by scanning techniques. In the laboratory, detailed observations of pecking may complement our knowledge of the effects of the physical structure of feed on pecking and the identification of the feed by broilers. The necessary validation of behavioural methods in commercial farms would benefit from increased interactions between field research and laboratory trials.

(C Elsevier/Inra)
\end{abstract}

\section{broiler / feed intake / behaviour / nutrition / growth / environment / learning / adaptation}

Résumé - Une approche comportementale de l'alimentation du poulet de chair. Les poussins utilisent leur bec dès la naissance pour briser la coquille de l'oeuf et picorer est l'une de leurs premières activités de vie autonome. Le picorage est un ensemble cordonné d'actions précises modulées par les caractéristiques physiques visuelles et tactiles des particules alimentaires. L'identification d'un aliment se construit par association de ses caractéristiques sensorielles avec ses effets post-ingestifs nutritionnels qui sont mémorisés. Quelques interactions entre facteurs nutritionnels (équilibres du régime en acides aminés et énergie, rationnement) et environnementaux (température, lumière) sont discutés à partir de travaux récemment publiés. Par exemple, le poulet peut s'adapter en plusieurs jours à des concentrations énergétiques très différentes du régime, si les aliments sont granulés ( 1950 à

\footnotetext{
* An abbreviated version of this paper was presented at the 1998 European Poultry Congress in Jerusalem, Israel.

** Correspondence and reprints.

Tel.: (33) 02474278 40; fax: (33) 02474277 78; e-mail: picard@ tours.inra.fr
} 
$3212 \mathrm{kcal} \cdot \mathrm{kg}^{-1}$ ), en revanche, en climat chaud il reste incapable d'ajuster son ingéré énergétique quelle que soit la teneur en acides aminés de l'aliment. Le bilan énergétique est la base de régulation de l'ingéré mais l'équilibre en acides aminés indispensables a plusieurs effets sur l'ingéré qui ne semblent pas explicables par la production de chaleur métabolique. Les poulets de chair ajustent leur budget temps en fonction des caractéristiques physiques et de la valeur nutritionnelle de l'aliment en équilibre avec d'autres contraintes environnementales comme le climat. Par exemple, les rythmes d'activité des poulets dépendent de l'équilibre en acides aminés indispensables de l'aliment mais aussi de la dureté des granulés et des fluctuations de la température. Dans les conditions de l'élevage, les caractéristiques biochimiques du régime sont calculées pour être nutritionnellement équilibrées et permettre une croissance musculaire rapide et efficace. Les caractéristiques physiques optimales des particules alimentaires sont connues avec moins de précision et l'observation du comportement des animaux pourrait conduire à des ajustements technologiques pour, par exemple, mieux contrôler le temps passé à la mangeoire des animaux ou faciliter les transitions entre deux livraisons d'aliment. De même, les techniques de distribution des aliments (heure, rythme) peuvent faciliter l'adaptation des poulets aux contraintes climatiques. Par exemple, un retrait de l'aliment avant les heures les plus chaudes de la journée couplé à un éclairement nocturne, limite la mortalité en finition. Dans ces deux domaines, technologie et rythmes de distribution de l'aliment, l'utilité des méthodes d'étude du comportement doit être validée au niveau de l'élevage. Cela nécessite un développement des interactions entre essais de laboratoire et mesures de terrain. (@) Elsevier / Inra)

poulet de chair / consommation d'aliment / comportement / nutrition / croissance / environnement / apprentissage / adaptation

\section{INTRODUCTION}

Feeding chickens has now reached a high degree of precision in determining animal requirements and biological availability of nutrients. The major instrument used to formulate a well-balanced diet is the biochemical evaluation of the feed. However, chickens peck mainly according to the physical characteristics of feed particles (meal, crumbs, pellets) that their sensory organs perceive.

Feed intake can be viewed as the medium-term result of feed pecking, which is a learned process modulated by memory of previously pecked particles. Observation of the behaviour of a broiler while eating is on a different time scale than feed intake as nutritionists measure it. Short-term variations in feed intake are sometimes considered as minor incidents. Nevertheless, field observations suggest that sometimes chickens under-eat for several hours (e.g. after a new delivery of feed is distributed), or overeat during certain times of the day (e.g. in the morning in warm climates). These short-term discrepancies have health impli- cations such as diarrhoea (when broilers eat too much litter material because they misidentify the new feed delivery) or mortality (when broilers overeat before a thermal peak).

Most of the current practical problems that exist in broiler production derive from interactions between genetic, nutrition, pathology and housing conditions. Some of these are difficult to measure at research stations because the reactions of the broilers may depend on environmental factors (e.g. the feed delivery system differs largely in most research situations from the farm). It may therefore be useful to develop techniques that might apply to feeding chickens at the farm level to analyse quantitatively the problems and evaluate solutions. Behavioural observations may be part of these techniques. One aim of this paper is to provide a framework of the study of feeding behaviour of broiler considering successively the various components of feed intake (figure 1).

Recent reviews on control of feed intake [15] and feed intake behaviour of chickens 


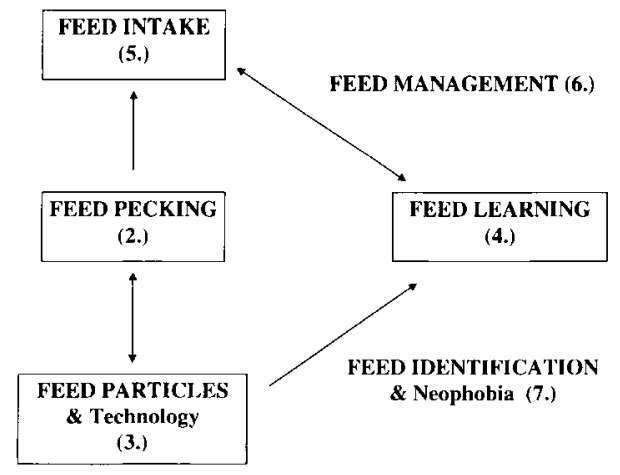

Figure 1. A schematic decomposition of feed intake behaviour in chickens. Pecking is the elementary act leading to feed intake but also to learning about feed particles. This process has practical consequences on feed identification, feed management and feed technology, which are analysed in the review (numbers refer to the sections of the text).

[58] substantiate the call made by Morris [45] for development of "adequate theories without waiting for a fundamental understanding of the complex and multidimensional system of appetite control in birds". Using a behavioural perspective, some recent publications on broiler nutrition are revisited in the present review. New directions of applied research will be based on speculative interpretations quoted at the end of each section as 'Implications' to separate them from the review of published scientific results.

\section{PECKING}

Chicks hatch using their beaks and one of their first activities after hatching is pecking (see [62] for review). In the absence of a parent, pecking can be stimulated by other chicks and even by an oscillating arrow [68]. Using nutritive and non-nutritive stimuli, Hogan [33] showed that pecking is, at the beginning of life, independent of hunger. Pecking followed by ingestion leads to the establishment of a feeding experience, and positive and negative feedback from the items pecked are responsible for early feed selection [30]. Many studies of early feed pecking development have been done using slow-growing chickens. Compared to jungle fowl or leghorn chicks, fast-growing broiler chicks have earlier and more rapid development of feed intake behaviour and digestive capabilities [53] associated with a faster resorption of residual yolk [69].

Pecking provides rewards in the form of nutrients which help to maintain body temperature and allow growth of tissues. Pecking also provides sensory information to complement visual cues, and recent reports show that olfactory cues may be more important in chicken nutrition than has been commonly assumed (see [37] for review). Pecking may be viewed as one of the means of sensory perception which are linked to ingestion. It is a precisely adjusted and rapid mechanism which can only be fully understood when video-taped pictures of the movements made by the skull and the beak are examined in slow motion [5]

At normal speed, the observation of a pecking suggests a continuous and indistinct repeated movement. In fact, the head of a young broiler remains stationary for $75 \%$ of the time during a continuous pecking session [77]. However, this relatively 'long' period for close observation of feed particles between pecks lasts less than $1 \mathrm{~s}$. This period not only allows swallowing or 'mandibulations', which occur only when a sufficient amount of feed has been grasped, but it is also a time when the chicken seems to gather additional information about the feed particles and chooses which particle to peck next. Yo et al. [77] showed that two of three pecks of young chickens did not aim at or seize a feed particle, suggesting that pecking is also associated with touching and thereby 'exploring' the feed [55].

Chickens go to the feed trough at irregular intervals which can hardly be described as meal feeding [64]. Feeding bout patterns (size, duration, intervals) can be biased by 
experimental design and the experimenter's definition of a feeding bout, i.e. parameters used to define what is the maximum duration of an eating pause allowed within the same bout [10]. Feeding bouts are dependent both on the necessary energy homeostasis of the body detected by production and dissipation of heat [75] and on environmental factors. Under operant conditioning conditions, when an animal has to work to obtain a reward, environmental constraints, such as the necessity to peck several times at a key for access to the feeder, reduce the randomness of the occurrence of feeding bouts [65]. In practice, social factors (competition and imitation, size of the group), feed management (frequency of filling of the trough, feed restriction), temperature fluctuations and lighting programmes can change feeding patterns $[9,51]$.

Analyses of organisation of feed pecking bouts over time may be useful for a more precise evaluation of the effects of environmental factors on time budgets of chickens. For example, when a diet is deficient in an essential amino acid, the time spent apparently eating increases but the feeding bouts are shorter [56], and when the temperature increases in the middle of the day in a poultry shed, the duration of the feeding bouts is reduced [61]. Thus, the measurement of the duration and frequency of accesses to a trough may indicate early in a poultry shed if broilers perceive and how they adapt to an environmental constraint. Methods that can be used in practice are briefly described at the end of section 5 .

\section{Implications}

Detailed observations of pecking behaviour at the laboratory level, using slowmotion video [77], may bring about a new evaluation of the feed itself, of its sensory perception by chickens and of the consequences of different physical characteristics of the particles. If a change in the diet is detected by chicks, they increase the duration of the observation between pecks and the number of effective pecks resulting in seizing a particle is reduced. A more detailed measurement of pecking in relation to the physical characteristics of the feed particles might lead in the future to a model predicting the broiler responses to the feed structure. A draft representation of a pecking model can be adapted for several domestic animals on a similar time-scale when an elementary act (here one peck) is considered (figure 2).

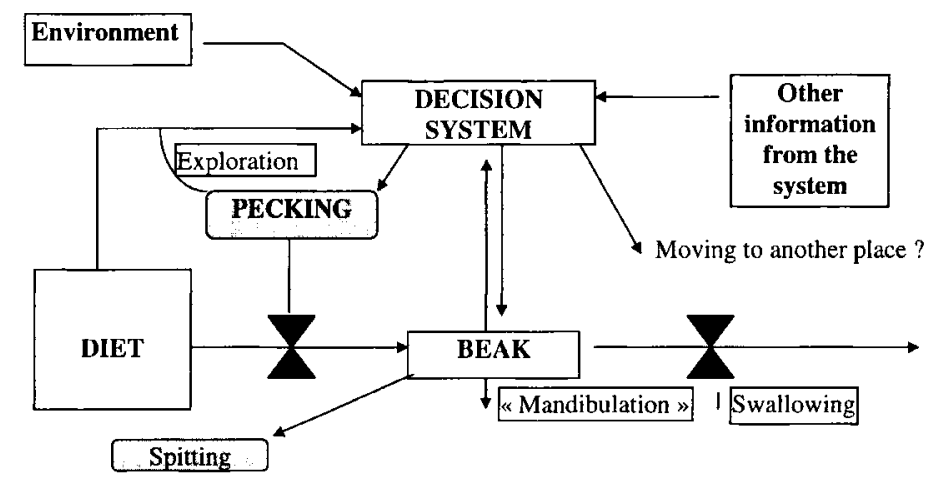

Figure 2. Control of pecking adapted from Faverdin and Picard [19]. The flow chart demonstrates the factors that control pecking at feed particles. Exploration pecks providing tactile information to the Decision System complement Diet cues (mainly visual and olfactory). Environmental factors (i.e. social and noise) can change pecking on a short-term basis. Other information from the system, such as motivation to eat or memory of the feed cues, can mediate medium- and short-term decisions. Similar models can easily be developed for mammals. 


\section{FEED PARTICLES}

The specificity of pecking in chickens and the sensitivity of the beak to differences in the structure of the particles seized or touched suggest that more attention needs to be given to the physical structure of feed particles. Such information has direct implications on the practical feed technology.

The colour [6,74] and odour [70] of a feed are precisely perceived by broilers. In chickens, each eye may have separate functions in feed identification and feed prehension due to brain lateralization $[62,71]$. Size, shape and hardness (i.e. resistance to crush) of the feed particles are important factors determined by feed milling. Young broilers prefer coarse particles of grain [50, 52], and the size and hardness of feed particles not only change the feed intake of broilers but also the development of their digestive tract, which may have several metabolic consequences (see [48] for review). Providing feed as pellets changes not only the particle size but the availability of the nutrients, such as carbohydrate in the feed, may be affected by the temperature increases in the meal during processing [31]. Contrary to early reports, however, physical form appears to be the major reason for increased feed intake and feed efficiency in broilers fed pellets rather than mash, because these improvements are abolished by the grinding of pellets [59]. When particles or crumbs of the same batches of maize and peas screened to the same size were introduced into a balanced diet ( $46 \%$ maize and $30 \%$ peas), broilers immediately identified the difference between particles and crumbs. They initially preferred the screened particles, but after 2 days they progressively changed their preference to the crumbs [57].

\section{Implications}

The identification of a feed particle is the result of sensory cues and associated postingestion information. Major traits in the sensory perception of the feed are: accurate vision of detail and precise tactile sensitivity of the beak within a complex and rapid pecking sequence [77]. In this context, a single, complete feed might be considered by chickens as the sum of feed particles whose homogeneity at the trough level is questionable.

Today the size of particles and quality of the manufactured pellets or crumbs are mainly designed to resist damage from the feed distribution system in order to deliver a homogeneous mix to the animal through. Feed technology of broiler diets require further consideration for various reasons:

- during their short life span, the beaks of young broilers grow and hence their perception of the physical characteristics of feed particles may change with age;

- characteristics of feed particles such as hardness, roughness and elasticity may influence the prehension of the feed and thus the time spent eating and the feed intake level under production conditions [58];

- feed identification or recognition by broilers seem mainly based on the physical characteristics (visual and tactile) of the feed particles (see section 7).

\section{FEED LEARNING}

Chickens have survived in a complex environment for millions of years by testing and selecting feed particles, none of which individually provide a balanced nutritional supply, and some of which are toxic. Chickens, like most animals, learned the characteristics of edible materials in their environment without chemical analyses and computerised calculations. For this purpose, they probably used detailed visual images of feed particles, repeated tactile experiences via the beak sensors, olfactory cues and various sensory messages from the digestive tract.

Collier [13] described feed intake and feed selection in animals as the result of a dialogue between the "house economist" 
and the "resident physiologist". The "house economist" represents the body of information gathered by observation and testing of feed sources available in the environment and the effort necessary to ingest them. The "resident physiologist" symbolises the biological demand for nutrients resulting in hunger. In modern broilers, the house economy is reduced to a single balanced diet that is provided constantly and the resident physiologist demand has been increased by genetic selection for rapid growth.

Several foraging theories propose optimisation of the benefit (intake)/cost (effort to eat) ratio in the medium term. However, domestic fowl work by pecking a disc to gain access to a feed which is simultaneously freely available in the same cage [16]. This situation is called 'contrafreeloading' and has also been observed in rats and cannot be simply explained 'economically' [26]. The necessity for chicks to test frequently possible alternative feed resources or the necessity to "find something to do" by captive chickens kept in a homogeneous environment are candidate explanations to contrafreeloading. More generally, the time window in which the eating decisions are optimised by birds is still largely unknown [14].

Learning is easily demonstrated experimentally when broilers are given a choice of diets [24]. Free-choice feeding allows the use of whole grain cereals with a complementary diet $[22,39,54]$. For example, the proportions of maize and complementary diets consumed by broilers from 15 to 42 days of age varied between $73 / 27$ when both were fed as a mash and 63/37 when maize was fed as whole grain and the complementary diet was pelleted [76]. These results suggest that broilers may not balance their diet only on the basis of metabolic feedback, but also on sensory stimuli and pecking cost.

Broilers provided with a choice of protein-rich and energy-rich diets did not eat to maximise growth or feed efficiency. At market weight they had consumed more energy and less protein than required for maximum muscle deposition and they were fatter than broilers fed a complete diet [66]. However, maximisation of meat yields with low-fat content in the carcass is a motivation for farmers and human consumers, but do not necessarily correspond to that of a chicken at the beginning of its life.

Broiler chicks fed alternately a sub-deficient diet in essential amino acids and a diet supplemented, by changing their feed every day, needed 1 week to identify the diets (or the rhythm of distribution). Although the reduction of intake observed after distribution of a sub-deficient diet initially takes more than $4 \mathrm{~h}$, after 1 week of adaptation, the broilers reduced their intake within the $1 \mathrm{st} h$ of the sub-deficient diet being offered [56]. Similar results were obtained with alternate low- and high-protein feeds, leading to the conclusion that broiler chicks can compensate for unbalanced diet if "they are able to gauge the sensory properties of the feeds" [25].

\section{Implications}

When the feeding experiences of broilers are varied by dietary choice or changes in diet, they are able to adapt, memorise and reevaluate new items or feed particles which had negative consequences. When given a choice, chickens usually continue to sample all edible materials available even if they eat quantitatively less feed of low nutritive value or with toxic effects [34]. Such behaviour was probably adaptive under conditions where feed resources were inconsistent, and of varying nutritional value or toxicity level and chickens had to remain informed of the available dietary alternatives. Contrafreeloading results might be explained by such a quest for information. "Adequate" choices and/or feed intake levels require precise feed identification [23], and a paradigm where such "adequacy" can be expressed [17]. In his review, Kyriazakis [38] considered that feeding behaviour of farm animals is "goal-orientated" and that 
this assumption might bring a better understanding of the way chicken, when given a choice, perceive the consequences of their diet on their comfort... if humans were able to identify these chicken's "goals"?

At present, free choice is not sufficiently understood to risk allowing broilers to determine their own diet, as they may not match the farmer's goal to optimise profits. However, feed learning may be a major issue because feed intake, at least on a shortterm basis, may be based on memorised representations of a feed and its nutritional value. This is considered in the following three sections on feed intake regulation, feed management and feed neophobia.

\section{FEED INTAKE}

Broilers have a propensity to rest which increases with age [7]. This 'propensity' may be due to their high metabolic rate and heat production and/or inactivity linked to physical constraints to locomotion. Eating represents the main non-resting activity of broilers, and given their bulimic-like intake associated with rapid growth, factors which predominantly regulate their feed intake require further consideration.

Broilers can adapt their medium-term feed intake to a wide range of feed types. For example, feeding pelleted diets varying in metabolizable energy from 1950 to $3212 \mathrm{kcal} \cdot \mathrm{kg}^{-1}$ did not change weight gain of broilers up to 49 days of age [40, 41]. In several experiments with various nutritional challenges, an interval of approximately 1 week was necessary for chickens to adjust their feed intake level $[56,64]$.

In other instances, broilers exposed to high environmental temperature were unable to adjust their feed intake regardless of the amino acid content of the diet $[1,11,12]$. Net energy yield or heat production have been suggested as explanations for variations in feed intake related to the protein balance of broiler diets [8]. Heat produc- tion was not increased by higher dietary protein levels in lean and fat broilers exposed to $32{ }^{\circ} \mathrm{C}$ [27]. Macleod [43] could not measure stimulation of heat production by the degradation of excess amino acids and suggested a direct effect of the amino acid balance on energy intake.

Two-week-old broilers rested for $76 \%$ of the time when fed a balanced diet ad libitum and only $56 \%$ when the same diet was sub-deficient in essential amino acids [56]. The feed intake adjustment of broilers to the amino acid balance of their diet is finely tuned and probably beyond what can be precisely measured under current experimental conditions. For example, using sound models of interpretation, the requirements for sulphur amino acids [3] and for lysine [72] are higher for maximal feed efficiency than for fastest growth. Given the definition of feed efficiency (growth/intake ratio), such differences can only be explained by a variation in feed intake.

\section{Implications}

Although there are numerous models that predict growth responses from the nutrient intake, the rate of feed intake needs to be accurately predicted and it is still a major area for future research [18]. The amount of feed ingested by a chicken depends on several factors in addition to the energy concentration of the diet, which would benefit from a closer evaluation. In recent unpublished results it appeared that variations in the fat content of broiler feed seem to induce almost no feed intake adaptation, while a diluent such as fibre lead to a more precise adjustment of the daily energy intake of broilers. In practice, feed intake of broilers is currently mostly regulated by environmental factors such as light, although, a few years ago, the introduction of a 5- to 6-h night would have been almost completely compensated for by overeating during the light phase.

For technical reasons, short-term variation in feed intake is not accurately con- 
trolled on most broiler farms. However, behaviour of broilers within large commercial flocks can be measured by simplified or adapted methods [46, 47, 61]. Repeated short (10 min) scanning of the number of chicken in a given activity, ie, eating from one trough, give relatively consistent evaluations of the time spent in one activity. Given the complexity of pecking [see section 2], this evaluation of the time spent at the trough cannot be accurately correlated with feed intake. However, within a farm, a change in regularly registered values can provide an early indication of a problem. Similarly, floor-oriented behaviours such as pecking or scratching at the litter vary in intensity, depending on the nutritional balance and the physical adequacy of the feed.

Focal observations of a single bird, taken at random within a large flock, were used in order to follow the duration of its stand until it once again rested. The duration of a recorded bout of activity depends on the age of the broiler, on the type of activities performed during that bout and on environmental factors (bird density, temperature, equipment). Consistent results were obtained when a sufficient number $(n>100)$ of bouts were recorded [61]. When practical decisions have to be taken, observation of the focal birds performed systematically at several farms of one integration seems to be a tool of potential value. The resultant behavioural data might complement records of feed input into a broiler shed (when available) by providing early signals of non-adaptation of the flock to its diet and/or its environment.

\section{FEED MANAGEMENT}

Feed management is a part of the environment of broilers and it has become an effective way to modulate growth and improve health. In practice, eating feed, the major non-resting activity of broilers, can be affected by factors such as flock density, the type of trough and the mode and frequency of feed distribution.
Feed restriction has been introduced in order to reduce leg disorders and circulatory problems of broilers by slowing early growth $[49,51]$. These increasingly frequent problems seem linked to a genetic selection, which has been oriented towards the utilisation of eaten nutrients for the growth of specific tissues such as gut and muscles [67]. Intermittent lighting [9] during the first 2 weeks after hatching induces an early delay in growth which is followed by compensatory growth [79]. The compensatory growth period seems almost independent of the nutritional balance of the diet offered [42], mainly during the week following the change in environment as a result of increased feed intake. In some instances, ad libitum feeding of a high energy diet is not the most efficient method to feed broilers. Feed restriction during the daylight can limit peaks of metabolic heat production during the warmest part of the day and help broilers to adapt to hot climatic conditions [75, 78].

\section{Implications}

The diet of the jungle fowl was probably never a single feed, constantly available, nor highly concentrated in nutrients. Feed management in the future might involve diets composed of several distinct feeds given according to a programme of distribution that would be adapted to environmental conditions and to the genotype requirements. Practical examples exist in Europe where diets including whole grain cereals simultaneously or sequentially offered to broilers with a complementary feed are being used [63]. More precise and systematic control of the behaviour of the chicken at the farm level would be useful for further developments of such feeding techniques. Changes in farming practices might also be validated by a more careful observation of individual and flock behaviours using the techniques briefly described in section 5 . 


\section{FEED NEOPHOBIA OR LACK OF FEED IDENTIFICATION?}

In their 40 days of life a broiler pecks more than 100000 times at pellets (many more if the diet is in mash form), and accumulate a significant sensorial experience of their feed. A minor change of diet can sometimes induce periods of non-eating (several hours). Are these transitory reactions due to the fear induced by the change, a relatively well-described mechanism called neophobia (fear of novelty) or do the chickens not eat for a time because they do not recognise or identify the feed as being an edible material, a reaction which could be distinct from fear?

A new feed can be at the same time attractive and induce reactions of fear as demonstrated by Hogan when jungle fowl chicks received a meal worm [32]. The genetic origin of the chicken can change their propensity to express hesitancy to eat unfamiliar feed. In this experiment, published by Jones [35], the heavier line tested expressed greater neophobia to an unusually coloured diet than the lighter line. There is limited published work comparing neophobic responses of genotypes and therefore it is difficult to generalise about the occurrence of feed neophobia. However, it seems to be observed more frequently in fast-growing birds such as turkeys and broilers than in slower-growing hybrids. Familiarisation to visual cues such as red-coloured water facilitates the latter consumption of a solution of vinegar $[20,21]$. This suggests that feed identification is based on a combination of learned cues or that a familiar cue has a reassuring effect which might reduce fear [36].

The reaction towards a new feed or unlearned aversion [44] is different from the learned aversion for a feed which has been associated with an induced malaise, such as via an injection of lithium chloride (i.e. [28]). Broadening the sensorial experience of a chicken by prior exposure to a variety of feed colours, for example [35], can reduce the latency to peck to a new diet. This enrichment of the environment or of the sensorial experiences of a chicken is known to have fear-reducing capacities [36]. Under commercial conditions, stimulating effects of environmental factors on learning in broilers are not obvious. Changing the environment by adding hanging mobiles has failed to improve feed intake and growth in broilers but does improve tibia strength [4]. Other experiments, however, suggest that enrichment of the environment of broilers can improve their performance [29].

With increasing age, broiler chicks reduce their exploration of the environment and their ability to detect hidden feed [73]. Whether this reduced ability is due to a reduction of locomotion linked to fast growth or to a insufficiently stimulating environment that favours routine behavioural patterns is open to debate. Red or white light has stimulated activity, while blue or green light has had a calming effect and seemed to be preferred [60]. In this experiment, as in others, chickens preferred the conditions with which they were familiar. Familiarisation with the colour of the feed has been described as "feed imprinting" by Bessei [6]. Familiarisation with a feed may reinforce the cues used by chickens to categorise, which is mainly controlled by the left hemisphere of the brain, although the right hemisphere is involved in response to novelty which determines neophobia $[2,55]$.

\section{Implications}

Reactions of broilers to a new feed might include a combination of simple non-identification modulated by the familiarity with the cues of the new feed and a fear reaction modulated by the habituation of the chicken to a homogeneous or enriched environment.

The chickens' awareness of their environment is probably 'global', e.g. simultaneously built by different facets corresponding to combinations of various cues 


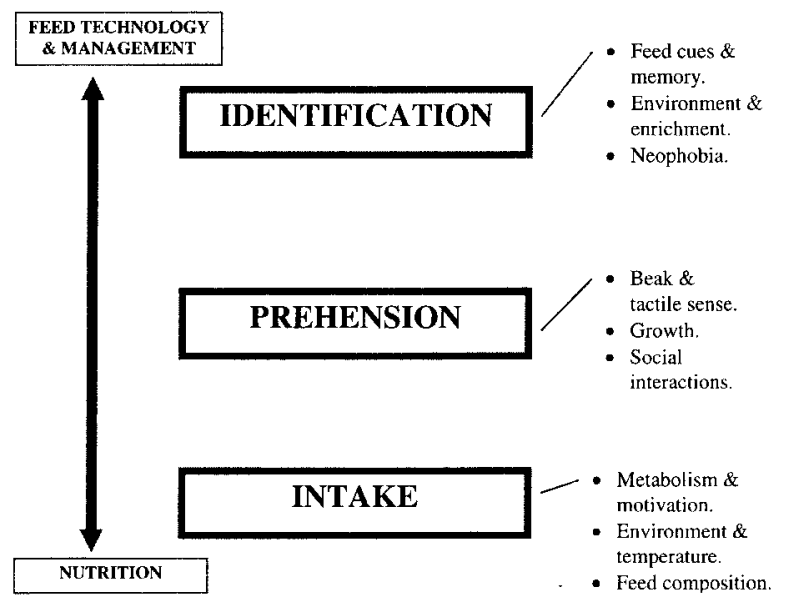

Figure 3. The three phases of feed intake behaviour. These three phases are regulated by various factors illustrated on the right of the figure. Genotype, age and environment of the chickens act on all three phases but by distinct paths. In practice, feed identification and prehension can be manipulated by feed technology and management, although medium-term feed intake remains mainly regulated by nutritional factors.

of their environment, with feed being just one part. Given their sensory capabilities, a single complete feed which appears homogeneous to humans might be considered by broilers as an aggregate of different feed particles. Environmental enrichment might consist of increasing the variety of feed particles and sensorial cues offered to broilers during their short life span. Given the importance of early experiences in feed learning, special attention should be paid to the starter diet that is given during a sensitive period when there may be long-term memory of the sensorial experiences (Lynch J., personal communication).

As the broiler ages, its perception of the environment focuses on its major non-resting activity: eating. Thus, the aspect of the feed, the 'feed image', may become more dominant with age. Familiarisation and learning have distinct roles in the feeding of broilers, with learning being essential to the identification and ingestion of a feed. Familiarity with a long established eating scheme in a homogeneous environment might hypothetically reduce the ability of the birds to accept a new feed [55].

\section{CONCLUSION}

The aim of nutritionists is to predict what a feed must contain in order to achieve optimal production. Medium-term feed intake is the essential variable taken into account for this purpose. However, under production conditions, the short-term reactions of broilers to their diet may involve distinct mechanisms of adaptation, such as feed identification and feed prehension (figure 3). Short-term rejection or non-identification of a perfectly formulated diet are sometimes observed. Behavioural criteria provide a way to evaluate the adaptation of chickens to their total environment (feed included), and therefore, a behavioural approach to feeding broilers may provide a complementary tool for the understanding of feed identification and feed prehension.

Pecking, a precise behaviour, requires further detailed observation using slow motion video techniques to identify the precise characteristics of the feed that are detected by the chickens. The duration of the observation period of the feed between two pecks, the ratio between exploratory 
and effective pecks, eating speed and temporal structures of feeding bouts are potentially new variables to explore. Also important to note is the sensorial cues of the feed and how broilers perceive them. Visual and tactile cues based on the physical characteristics of feed particles relevant to feed technology determine feed identification and prehension.

Feed memorisation appears to be a learning process that interacts with other environmental factors conditioning the sensorial experience of a chicken. Creating familiarity with a known cue may be a way to facilitate recognition of a feed and/or to reduce fear. Enrichment by increasing the diversity of the sensorial experiences of broilers at an early age may also decrease fear and aid adaptation to new diets. Feed and environment management offer an area of investigation to facilitate adaptation of the future broiler genotypes. The improvements resulting from such investigations will require intensified field research, including behavioural observations coupled with laboratory trials.

Nutritionists have greatly improved the chemical composition of feeds. However, the physical characteristics of the feed particles are also very important for the bird, and a research effort in this area may be beneficial to short- and medium-term acceptability of feed by broilers.

\section{ACKNOWLEDGEMENTS}

We are very grateful to $\mathrm{C}$. Beaumont, G. Hinch, J. Lynch, I. Nir, J. Nolan and P. Siegel for their essential comments on early versions of the manuscript and to D. Raine for correction of the English language.

\section{REFERENCES}

[1] Alleman F., Leclercq B., Effect of dietary protein and environmental temperature on growth performance and water consumption of male broiler chickens, Br. Poult. Sci. 38 (1997) 607-610.
[2] Alonzo Y., Lateralization of visual guided behaviour during feeding in zebra finches (Taeniopygia guttata), Behav. Process. 43 (1998) 257-263.

131 Baker D.H., Fernandez S.R., Webel D.M., Parsons C.M., Sulfur amino acid requirement and cystine replacement value of broiler chicks during the period three to six weeks posthatching, Poult. Sci. 75 (1996) 737-742.

[4] Balog J.M., Bayyari G.R., Rath N.C., Huff W.E., Anthony N.B., Effect of intermittent activity on broiler production parameters, Poult. Sci. 76 (1997) 6-12.

[5] Bermejo R., Zeigler H.P., Prehension in the pigeon. II. Kinematic analysis, Exp. Brain Res. 75 (1989) 577-585.

[6] Bessei W., Eine Untersuchung zur Futterprägung bei Hühnerküken, in: Proceedings of the European Poultry Science Congress, Hamburg, Germany, 1980, vol. 4, pp. 145-152.

[7] Bessei W., Das Verhalten von Broilern unter intensiven Haltungsbedingungen, Arch. Gelflugelkd. 56 (1992) 1-7.

[8] Boorman K.N., Ellis G.M., Maximum nutritional response to poor-quality protein and amino acid utilisation, Br. Poult. Sci. 37 (1996) 145-156.

[9] Buyse J., Simons P.C.M., Boshouwers F.M.G., Decuypere E., Effect of intermittent lighting, light intensity and source on the performance and welfare of broilers, World Poult. Sci. J. 52 (1996) $121-130$.

[10] Castonguay T.W., Kaiser L.L., Stern J.S., Meal pattern analysis, artifacts, assumptions and implications, Brain Res. Bull. 17 (1986) 439-443.

[11] Cheng T.K., Hamre M.L., Coon C.N., Effect of environmental temperature, dietary protein and energy levels on broiler performance, J. Appl. Poult. Res. 6 (1997) 1-17.

[12] Cheng T.K., Hamre M.L., Coon C.N., Responses of broilers to dietary protein levels and amino acid supplementation to low protein diets at various environmental temperatures, J. Appl. Poult. Res. 6 (1997) 18-33.

[13] Collier G., The dialogue between the house economist and the resident physiologist, Nutr. Behav. 3 (1986) 9-26.

[14] Collier G., Johnson D.J., The time-window of feeding, Physiol. Behav, 48 (1990) 771-777.

[15] Denbow D.M., Appetite and its control, Poult. Sci. Rev. 5 (1994) 209-229.

[16] Duncan I.J.H., Hughes B.O., Free operant feeding in domestic fowls, Anim. Behav. 20 (1972) 775-777.

[17] Emmans G.C., Diet selection by animals: theory and experimental design, Proc. Nutr. Soc. 50 (1991) 59-64.

[18] Emmans G.C., Problems in modelling the growth of poultry, World Poult. Sci. J. 51 (1995) 77-89. 
[19] Faverdin P., Picard M., Préhensibilité des aliments par les herbivores et les volailles. Avantpropos, Inra Prod. Anim. 10 (1997) 375.

[20] Franchina J.J., Mere exposure to telereceptive cues facilitates intake of novel flavor in chickens (Gallus domesticus), Behav. Neural. Biol. 56 (1991) 108-112.

[21] Franchina J.J., Slank K.L., Role of telereceptive and interoceptive (Taste) cues in ingestional neophobia in chicks (Gallus domesticus), Behav. Neural. Biol. 52 (1989) 116-122.

[22] Forbes J.M., Covasa M., Application of diet selection by poultry with particular reference to whole cereals, World Poult. Sci. J. 51 (1995) 149-165.

[23] Forbes J.M., Kyriazakis I., Food preferences in farm animals: why don't they always choose wisely? Proc. Nutr. Soc. 54 (1995) 429-440.

[24] Forbes J.M., Shariatmadari F., Diet selection for protein by poultry, World Poult. Sci. J. 50 (1994) 7-24.

[25] Forbes J.M., Shariatmadari F., Short-term effects of protein content on subsequent diet selection by chickens and the consequences of alternate feeding of high- and low-protein foods, $\mathrm{Br}$. Poult. Sci. 37 (1996) 597-607.

[26] Gallo A., Cuq C., « Contrafreeloading » et localisation de l'agent renforcateur, Behav. Process. 14 (1987) 11-20.

[27] Geraert P.A., Guillaumin S., Leclercq B. Are genetically lean broilers more resistant to hot climate? Br. Poult. Sci. 34 (1993) 643-653.

[28] Gillette K., Martin G.M., Bellingham W.P., Differential use of food and water cues in the formation of conditioned aversions in domestic chicks (Gallus gallus), J. Exp. Psych. Anim. Behav. Proc. 6 (1980) 99-111.

[29] Gvaryahu G., Cunningham D.L., Van Thienhoven A., Filial imprinting, environmental enrichment, and music application effects on behavior and performance of meat strain chickens, Poult. Sci. 68 (1989) 211-217.

[30] Hale C., Green L., Effects of early ingestional experiences on the acquisition of appropriate food selection by young chicks, Anim. Behav. 36 (1988) $211-224$.

[31] Hamilton R.M.G., Proudfoot F.G., Ingredient particle size and feed texture: effects on the performance of broiler chickens, Anim. Feed Sci. Technol. 51 ( 1995) 203-210.

[32] Hogan J.A., An experimental study of conflict and fear: an analysis of behavior of young chicks toward a mealworm. 1. The behavior of chicks which do not eat the mealworm, Behaviour 25 (1965) 45-95.

[33] Hogan J.A., Pecking and feeding in chicks, Learn. Motiv. 15 (1984) 360-376.

[34] Hogan-Warburg A.J., Hogan J.A., Feeding strategies in the development of food recognition in young chicks, Anim. Behav. 29 (1981) $143-154$.
[35] Jones R.B., Responses of domestic chicks to novel food as a function of sex, strain and previous experience, Behav. Process. 12 (1986) 261-271.

[36] Jones R.B., Fear and adaptability in poultry: insights, implications and imperatives, World Poult. Sci. J. 52 (1996) 131-174.

[37] Jones R.B., Roper T.J., Olfaction in the domestic fowl: a critical review, Physiol. Behav. 62 (1997) 1009-1018.

[38] Kyriazakis I., The nutritional choices of farm animals: to eat or what to eat? In: Forbes J.M., Lawrence T.L.J., Rodway R.G., Varley M.A. (Eds.), Animal Choices, Occasional Publication of the British Society of Animal Science, 20 (1997) 55-65.

[39] Leeson S., Caston L.J., Production and carcass yield of broilers using free-choice cereal feeding, J. Appl. Poult. Res. 2 (1993) 253-258.

[40] Leeson S., Caston L., Summers J.D., Broiler response to energy or energy and protein dilution in the finisher diet, Poult. Sci. 75 (1996) 522-528.

[41] Leeson S., Caston L., Summers J.D., Broiler response to diet energy, Poult. Sci. 75 (1996) 529-535.

[42] Leeson S., Zubair A.K., Nutrition of the broiler chicken around the period of compensatory growth, Poult. Sci. 76 (1997) 992-999.

[43] Macleod M.G., Effects of amino acid balance and energy:protein ratio on energy and nitrogen metabolism in male broiler chickens, Brit. Poult. Sci. 38 (1997) 405-41 1.

[44] Marples N., Roper T.J., Effects of novel colour and smell on the response of naive chicks towards food and water, Anim. Behav. 51 (1996) 1417-1424.

[45] Morris T.R., Poultry science: the next 20 years? Br. Poult. Sci. 37 (1996) 5-14.

[46] Murphy L.B., Preston A.P., Food availability and the feeding and drinking behaviour of broiler chickens grown commercially, Br. Poult. Sci. 29 (1988) 273-283.

[47] Murphy L.B., Preston A.P., Time-budgeting in meat chickens grown commercially, Br. Poult. Sci. 29 (1988) 571-580.

[48] Nir I., The effects of food particle size and hardness on performance: nutritional, behavioral and metabolic aspects, in: Proceedings of the 20th World's Poultry Science Congress, New Delhi, India, 2-5 September 1996, vol. 2, pp. 173-184.

[49] Nir I., Interaction of genetic stocks, growth rate, feeding regime and metabolic diseases, in: Proceedings of the 10th European Poultry Conference, Jerusalem, Israel, 21 -26 June 1998, vol. 1, pp. 105-112.

[50] Nir I., Melcion J.P., Picard M., Effect of particle size of sorghum grains on feed intake and performance of young broilers, Poult. Sci. 69 (1990) 2177-2184. 
[51] Nir l., Nitsan Z., Dunnington E.A., Siegel P.B., Aspects of food intake restriction in young domestic fowl: metabolic and genetic considerations, World Poult. Sci. J. 52 (1996) 251-266.

[52] Nir I., Shefet G., Aaroni Y., Effect of particle size on performance. 1. Corn, Poult. Sci. 73 (1994) 45-49.

[53] Noy Y., Sklan D., Posthatch development in poultry, J. Appl. Poult. Res. 6 (1997) 344-354.

[54] Olver M.D., Jonker A., Effect of choice feeding on the performance of broilers, Br. Poult. Sci. 38 (1997) 571-576.

[55] Picard M., Broiler behaviour and nutritional conditions, in: Proceedings of the 1lth European Symposium on Poultry Nutrition, Faaborg, Denmark, 24-28 August 1997, pp. 175-180.

[56] Picard M., Faure J.M., Siegel P.B., Dunnington E.A., Uzu G., Dalibard P., Food Intake and Amino Acids in Poultry, Rhône Poulenc Animal Nutrition, Antony, France, 1994, 44 p.

[57] Picard M., Giboulot B., Melcion J.P., Miettes ou éclats de graines d'aspects semblables sont identifiés par le jeune poulet, in : Proc. $2^{\mathrm{e}}$ Journées de la recherche avicole, Tours, France, 8-10 avril 1997, vol. 2, pp. 197-200.

[58] Picard M., Melcion J.P., Bouchot C., Faure J.M., Picorage et préhensibilité des particules alimentaires chez les volailles, Inra Prod. Anim. 10 (1997) 403-414.

[59] Plavnik I., Wax E., Sklan D., Hurwitz S., The response of broiler chickens and turkey poults to steam-pelleted diets supplemented with fat or carbohydrates, Poult. Sci. 76 (1997) 1006-1013.

[60] Prayitno D.S., Phillips C.J.C., Omed H., The effects of color of lighting on behavior and production of meat chickens, Poult. Sci. 76 (1997) 452-457.

[61] Richard P., Vilariño M., Faure J.M., Leon A., Picard M., Étude du comportement du poulet de chair dans un élevage intensif tropical au Venezuela, Rev. Elev. Med. Vet. Pays Trop. 50 (1997) 65-74.

[62] Rogers L.J., The Development of the Brain and Behaviour in the Chicken, $\mathrm{CAB}$ International, Wallingford, UK, 1995, pp. 95-110.

163] Rose S.P., Fielden M., Foote W.R., Gardin P., Sequential feeding of whole wheat to growing broiler chickens, Br. Poult. Sci. 36 (1995) 97-111.

[64] Savory C.J., Feeding behaviour, in: Boorman K.N., Freeman B.M. (Eds.), Food Intake Regulation in Poultry, Br. Poult. Sci., Edinburgh, UK, 1979, pp. 277-323.

[65] Savory C.J., Responses of fowls to an operant feeding procedure and its potential use for reducing randomness of meal occurrence, Physiol. Behav. 45 (1989) 373-380.

[66] Siegel P.B., Picard M., Nir I., Dunnington E.A., Willemsen M.H.A., Williams P.E.V., Responses of meat-type chickens to choice feeding of diets differing in protein and energy from hatch to market weight, Poult. Sci. 76 (1997) 1183-1192.

167] Siegel P.B., Dunnington E.A., Ressource allocations: growth and immune responses, in: Proceedings of the 10th European Poultry Conference, Jerusalem, Israet, 21-26 June 1998, vol. 1, pp. $98-98$.

[68] Suboski M.D., Bartashunas C., Mechanisms for social transmission of pecking preferences to neonatal chicks, J. Exp. Psychol. Anim. Behav. Process. 10 (1984) 182-194.

[69] Turro I., Dunnington E.A., Nitsan Z., Picard M., Siegel P.B., Effect of yolk sac removal at hatch on growth and feeding behavior in lines of chickens differing in weight, Growth Develop. Aging 58 (1994) 105-1 12.

[70] Turro I., Porter R.H., Picard M., Olfactory cues mediate food selection by young chicks, Physiol. Behav. 55 (1994) 761-767.

[71] Vallortigara G., Regolin L., Bortolomiol G. Tommasi L., Lateral asymmetries due to preferences in eye use during visual discrimination learning in chicks, Behav. Brain Res. 74 (1996) 135-143.

172] Vazquez M., Pesti G.M., Estimation of the lysine requirement of broiler chicks for maximum body gain and feed efficiency, J. Appl. Poult. Res. 6 (1997) 241-246.

173] Vilariño M., Leon A., Faure J.M., Picard M., Ability of broiler chicks to detect hidden food, Arch. Gelflugelkd. 62 (1998) 156-162.

[74] Weeks C.A., Brooks C., Coe G., Danbury T.C., Effect of food and feeder colour on food consumption of young layers and broilers, Brit. Poult. Sci. 38 (Supp1.) (1997) S17.

175] Wiernusz C.J., Teeter R.G., Acclimation effects on fed and fasted broiler thermobalance during thermoneutral and high ambient temperature exposure, Br. Poult. Sci. 37 (1996) 677-687.

176| Yo T., Siegel P.B., Guérin H., Picard M., Selfselection of dietary protein and energy by broilers grown under a tropical climate: effect of feed particle size on the feed choice, Poult. Sci. 76 (1997) 1467-1473.

177] Yo T., Vilariño M., Faure J.M., Picard M., Pecking in young chickens: new techniques of evaluation, Physiol. Behav. 61 (1997) 803-810.

[78] Zhou W.T., Yamamoto S., Effects of environmental temperature and heat production due to food intake on abdominal temperature, shank skin temperature and respiration rate of broilers, Br. Poult. Sci. 38 (1997) 107-114.

[79] Zubair A.K., Leeson S., Compensatory growth in the broiler chicken: a review, World Poult. Sci. J. 52 (1996) 189-20l. 